\title{
DEMOCRACIA, POPULISMO REACIONÁRIO E CHANTAGEM NEOLIBERAL
}

\author{
Angelo Girotto Neto ${ }^{1}$
}

\begin{abstract}
Resumo
Este artigo se propõe a revisar o debate sobre a atual crise das democracias liberais a partir das obras Ruptura: a crise da democracia liberal, de Manuel Castells; O povo contra a democracia, de Yascha Mounk; Como as democracias morrem, de Steven Levitsky e Daniel Ziblatt. Na primeira seção, analisamos os aspectos essenciais contidos nas obras referidas acerca da consolidação dos regimes democrático-liberais e dos fatores centrais de sua crise de legitimidade. Na segunda, discute-se como tal crise de legitimidade se associa à ascensão do populismo reacionário. Na terceira parte, problematizamos as análises revisadas, buscando apontar os limites políticos da disputa corrente entre o populismo reacionário e o neoliberalismo progressista, conceitos que vamos buscar em Nancy Fraser. A partir da revisão crítica desses textos e com apoio em outros analistas, a hipótese sugere que os debates acerca da atual crise nas democracias liberais se desenvolvem em termos de uma chantagem neoliberal, onde o conceito de populismo serve também ao propósito de excluir do debate político diversos movimentos sociais antissistema, prevalecendo os interesses econômicos hegemônicos do capital financeirizado.
\end{abstract}

Palavras-chave: Democracia. Populismo. Neoliberalismo.

\begin{abstract}
This article aims to review the debate on the current crisis of liberal democracies based on the works Ruptura: the crisis of liberal democracy, by Manuel Castells; The People Against Democracy, by Yascha Mounk; How Democracies Die, by Steven Levitsky and Daniel Ziblatt. In the first section, we analyze the essential aspects contained in the works referred to about the consolidation of liberal-democratic regimes and the central factors of their legitimacy crisis. The second discusses how such a crisis of legitimacy is associated with the rise of reactionary populism. In the third part, we problematize the revised analyses, seeking to point out the political limits of the current dispute between reactionary populism and progressive neoliberalism, concepts that we will look for in Nancy Fraser. Based on the critical review of these texts and with support from other analysts, the hypothesis suggests that debates about the current crisis in liberal democracy develop in terms of a neoliberal blackmail, where the concept of populism also serves the purpose of excluding from the political debate several anti-system social movements, prevailing the hegemonic economic interests of financialized capital.
\end{abstract}

Keywords: Democracy. Populism. Neoliberalism.

\section{Resume}

Este artículo tiene como objetivo revisar el debate sobre la crisis actual de las democracias liberales a partir de las obras Ruptura: la crisis de la democracia liberal, de Manuel Castells; El pueblo contra la democracia, de Yascha Mounk; Cómo mueren las democracias, de Steven Levitsky y Daniel Ziblatt. En el primer apartado, analizamos los aspectos esenciales contenidos en los trabajos referidos sobre la consolidación de los regímenes liberal-democráticos y los factores centrales de su crisis de legitimidad. El segundo analiza cómo esta crisis de legitimidad está asociada con el surgimiento del populismo reaccionario. En la tercera parte discutimos los análisis revisados, buscando señalar los límites políticos de la disputa actual entre populismo reaccionario y neoliberalismo progresista, conceptos que buscaremos en Nancy Fraser. A partir de la revisión crítica de estos textos y con el apoyo de otros analistas, la hipótesis sugiere que los debates sobre la actual crisis de la democracia liberal se desarrollan en términos de un chantaje neoliberal, donde el

\footnotetext{
${ }^{1}$ Doutor em Ciências Sociais pela Universidade Federal do Rio Grande do Norte (UFRN).
} 
concepto de populismo también sirve para excluir del debate político a varios movimientos sociales antisistema, prevaleciendo los intereses económicos hegemónicos del capital financiarizado.

Palabras clave: Democracia. Populismo. Neoliberalismo.

\section{INTRODUÇÃO}

A crescente preocupação com a vitalidade das democracias liberais no mundo se dá muito em resposta à ascensão de lideranças e partidos políticos portadores de um discurso populista de viés autoritário, como nos casos recentes de Brasil, EUA, Polônia, Índia e Hungria. Essa vaga populista comporta um grande número de atores e envolve diversos países de regiões e características diferenciadas. $\mathrm{O}$ desrespeito às regras de convivência democrática e a crença num Estado repressor atuante na contenção das liberdades de minorias são traços em comum dos diversos atores do populismo reacionário que ascenderam aos governos por todo o globo, cada qual conformando seu discurso às condições particulares de seu país, dando maior ou menor centralidade à xenofobia, à intolerância religiosa, às questões de gênero e direitos das minorias.

Contudo, muito embora a emergência desse campo populista no mundo acentue a gravidade da crise das democracias liberais, os dilemas enfrentados por estas precedem o atual cenário político internacional. Ainda na década de 1980, Norberto Bobbio já apontava para a necessidade de se enfrentar os desafios não previstos e as promessas não cumpridas pela “democracia real”. O autor de O futuro da democracia (2018 [1984]) ressaltava os riscos contidos na redução dos espaços democráticos nas arenas do poder, na persistência do poder invisível e das oligarquias, na nunca concretizada educação dos cidadãos, entre outros. A democracia não é uma conquista unidirecional, muito mesmo consensual. Tanto em sua definição quanto em sua existência prática, ela tem variado significativamente com o tempo e o espaço. Para construir um corpo analítico capaz de lidar com tal variedade de contextos e conformações, Bobbio nos fornece uma definição ampla de democracia, que será útil no decorrer do debate: "um conjunto de regras (primárias ou fundamentais) que estabelecem quem está autorizado a tomar decisões coletivas e com quais procedimentos" (2018, p. 35). Dentro do sistema bobbiano de definições por dicotomias, a democracia é a forma de governo que se contrapõe aos regimes autocráticos. Essa definição relacional democracia-autocracia estabelece aqui as bases necessárias para uma leitura integrada dos autores que revisamos, cada qual com sua definição particular do que seria a democracia.

Este artigo se propõe a revisar o debate sobre a atual crise das democracias liberais a partir das obras Ruptura: a crise da democracia liberal, de Manuel Castells (2018); O povo contra a democracia, de Yascha Mounk (2019); e Como as democracias morrem, de Steven Levitsky e Daniel Ziblatt (2018). 
A metodologia adotada se atém a uma revisão de literatura analítica. Para tanto, na primeira parte, analisamos os aspectos essenciais contidos nas obras referidas acerca da consolidação dos regimes democrático-liberais e dos fatores centrais de sua crise de legitimidade. Na segunda parte, discute-se como tal crise de legitimidade se associa à ascensão do populismo reacionário. $\mathrm{Na}$ terceira parte, problematizamos as análises revisadas, buscando apontar os limites políticos da disputa corrente entre o populismo reacionário e o neoliberalismo progressista, conceitos que vamos buscar em Nancy Fraser. Na conclusão, retomamos brevemente os principais elementos de nossa crítica, reafirmando a hipótese levantada de que os debates acerca da atual crise nas democracias liberais se desenvolvem em termos de uma chantagem neoliberal, onde o conceito de populismo serve também ao propósito de excluir do debate político diversos movimentos sociais antissistema de origem popular.

\section{QUAL A CRISE NA DEMOCRACIA LIBERAL?}

No mundo pós-guerras do século XX, as sociedades globais - que se constituíram a partir da integração internacional dos processos produtivos e da redução sem precedentes das distâncias físicas e temporais possibilitadas pelo rápido avanço tecnológico - vivenciaram a hegemonia de dois modos distintos de construção do consenso social e legitimação das instituições do poder estatal. De um lado, o bloco liderado pela União das Repúblicas Socialistas Soviéticas (URSS) se estruturava em torno do socialismo real e suas formas de representação e legitimação do poder. Já as democracias liberais, foram o sistema de organização do Estado prevalente no bloco de países capitalistas que emerge do pós-guerras sob a hegemonia inconteste dos EUA, confirmados como a principal potência econômica, militar e cultural do novo cenário internacional emergente.

No período que vai do fim da $2^{\mathrm{a}}$ Grande Guerra ao início dos anos 1970, as democracias liberais viveram uma fase de estabilidade inédita em sua breve história na vida política global, considerando-se aqui as maiores potências econômicas mundiais. Esse é o período que o historiador inglês Eric Hobsbawm chamou de era de ouro, que corresponde quase exatamente ao terceiro quartil do breve século XX, que, na cronologia do historiador inglês, termina com a dissolução da URSS no princípio dos anos 1990. A era de ouro do século XX coincidiu com a era de ouro das democracias liberais. Hobsbawm (1994) constatou que, ao final dessa era, pela primeira vez na história multimilenar das sociedades humanas, era possível afirmar com certeza que a maioria da população mundial tinha acesso diário à quantidade mínima de calorias necessárias para a manutenção do corpo humano. Isso não é pouco, ainda mais se considerado o curto espaço de tempo em que tal conquista ocorre, pouco mais de duas décadas. Contribuíram 
muito para tal fenômeno o impressionante crescimento econômico da URSS, que também, em brevíssimo espaço de tempo, realizou um intenso processo de industrialização que permitiu o acesso ao consumo a milhões de pessoas cujos pais ou avós viveram numa sociedade semifeudal. Outra força determinante no processo de inclusão da maior parte da população mundial no sistema produtivo global foi o progresso tecnológico inédito associado à expansão do modo de produção capitalista.

$\mathrm{Na}$ era de ouro, as populações dos principais países da economia capitalista central nações como os EUA, Inglaterra, França, Alemanha, Canadá - viram a renda média das famílias duplicar a cada geração. Assim, a geração que entrou no mercado de trabalho, entre os anos 1940 e 1950, nesses países, tinha a realista perspectiva de alcançar um poder aquisitivo duas vezes maior que o de seus pais; o mesmo seria verdade para seus filhos. Tanto Hobsbawm (1996, 2007), quanto Yascha Mounk (2019) e Manuel Castells (2018) são unânimes ao enxergar nesse cenário um fator decisivo para o enorme êxito das democracias liberais na era de ouro. Hobsbawm assim definiu a situação:

Nos países onde a tradição de governos representativos estava estabelecida havia muito
tempo, ela era aceita não só porque os sistemas alternativos pareciam ser piores, mas
também porque, ao contrário do que ocorrera na terrivel era das guerras e das
catástrofes econômicas mundiais, muito poucas pessoas sentiam a necessidade de um
sistema alternativo - particularmente em uma era de prosperidade geral, que melhorou
as condições de vida até dos pobres, e de sistemas robustos de bem-estar social. (2007,
p. 101)

O Estado do bem-estar social surge não apenas como alternativa às pressões oriundas do exemplo socialista, sempre pairando como fonte de comparações e inspiração para movimentos sociais de todo o mundo, como também na forma de um eficiente mecanismo para enfrentar as crescentes adversidades surgidas numa sociedade de produção e consumo de massas. Ao permitir acesso a parte do progresso material das sociedades do capitalismo desenvolvido, as políticas de bem-estar ampliaram enormemente as bases sociais da legitimação das democracias liberais, conforme exposto por Hobsbawm. Ainda, as políticas de redistribuição de renda ampliaram o mercado consumidor, de forma a dar vazão à crescente capacidade produtiva das nações tecnologicamente mais desenvolvidas, engendrando um círculo virtuoso de incremento produtivo e inserção de novas multidões no mercado de trabalho.

Outro fator essencial na força das democracias liberais foi seu confronto com os regimes alternativos que se opunham como alternativa real e "ameaça imediata", os regimes socialistas. Se por um lado a pressão vinda do Leste, pelo exemplo da URSS, contribuiu para a definição das políticas de Estado no Ocidente capitalista, por outro, também serviu de barricada aos regimes 
liberais, defendidos como necessária proteção à "ameaça comunista”. Seria incauto desconsiderar a importância dessa identidade pela negação do outro no vigor que desfrutou a democracia liberal na segunda metade do século XX. Esse pressuposto, implícito em graus variados e muitas vezes explícitos, está nos alicerces mesmo de obras contemporâneas que buscam denunciar os riscos atuais à democracia, como em Mounk ou Steven Levitsky e Daniel Ziblatt, autores de Como as democracias morrem.

Levitsky e Ziblatt creditam ainda grande parte da excepcional vitalidade da democracia representativa nos EUA ao sistema madisoniano de freios e contrapesos, que teria resistido bem às intempéries de mais de dois séculos. A Constituição norte-americana foi concebida pelos federalistas com o firme propósito de orientar a construção de um governo representativo que se protegesse do que era então identificado como os "riscos da democracia", especialmente aquele de o poder ser utilizado para além dos fins para os quais foi constituído, gerando concentração de poder e despotismo, ainda que um despotismo da maioria. Esse modelo institucional influenciou toda a trajetória democrática de nossa região. Levitsky e Ziblatt registram:

[...] pensemos na experiência pós-colonial na América Latina. Muitas das repúblicas recém-independentes se basearam diretamente nos Estados Unidos, adotando o presidencialismo, o legislativo bicameral, as supremas cortes ao estilo norte-americano e, em alguns casos, colégios eleitorais e sistemas federais. Algumas escreveram constituições que eram quase réplicas da Constituição dos Estados Unidos. (2018, p. 100)

De todos os elementos centrais destacados pelos autores, apenas o colégio eleitoral difere essencialmente no Brasil do modelo herdado pelo exemplo norte-americano. Então nos perguntamos: em que medida os freios e contrapesos seriam bastantes para assegurar as democracias representativas? Levitsky e Ziblatt respondem que não muito.

Se regras constitucionais bastassem, figuras como Perón, Marcos e Getúlio Vargas todos os quais assumiram os cargos sob constituições ao estilo norte-americano, que continham, no papel, um arranjo ordenado de freios e contrapesos - teriam sido presidentes de um ou dois mandatos, em vez de autocratas notórios. (2018, p. 100)

Para além das regras constitucionais, os autores apontam dois fatores que teriam sido decisivos para a sobrevivência dos regimes democráticos liberais, em especial seu modelo mais bem-sucedido, na visão dos autores, os EUA: tolerância mútua e contenção. A tolerância mútua refere-se à noção de que os oponentes, mesmo derrotados, possuem o direito de seguir disputando as esferas de poder e a opinião pública, de que seus pontos de vista são válidos e permitidos. A contenção diria respeito à aceitação aos limites da livre disputa democrática, no sentido de que "os políticos devem ser comedidos ao fazerem uso de suas prerrogativas institucionais" (2018, p. 20), sobretudo em não usar o poder a eles atribuídos com o propósito de 
obter vantagens institucionais indevidas sobre seus concorrentes. Essas seriam, segundo os autores, as regras não escritas da democracia. O desrespeito a tais regras informais, que teriam sido aceitas pelos políticos ou impostas pelo contrapeso das instituições democráticas, seria a marca da crise democrática que os autores associam principalmente à vitória e a condução de Donald Trump nos EUA.

O momento a partir do qual Levitsky e Ziblatt veem a escalada do desrespeito às regras informais da democracia se aproxima do período inicial daquilo a que Hobsbawm (1995) chama de as décadas de crise, que se iniciam nos anos 1970 e vão até 1991, com o fim da URSS. Os primeiros, contudo, veem na eleição de Trump um momento de ruptura na trajetória das democracias liberais.

Hobsbawm está entre os que propõem que a crise das democracias liberais é uma crise de legitimidade, que remonta às transformações históricas que marcam as décadas de crise. Já Manuel Castells, em Ruptura, assim resume a questão, indo ao encontro das teses de Mounk: "Se for rompido o vínculo subjetivo entre o que os cidadãos pensam e querem e as ações daqueles a quem elegemos e pagamos, produz-se o que denominamos crise de legitimidade política" (2018, p. 12).

Mounk (2019) segue à sua análise dos anos de ouro da democracia liberal a demonstração de como as coisas começam a mudar a partir dos anos 1970. Se, como já exposto, nos anos de ouro, as gerações podiam nutrir a esperança de ter uma renda familiar duas vezes superior a de suas predecessoras, a partir de então tal expectativa deixa de ser realista. Em diversos dos países analisados - dentre os quais EUA, França, Inglaterra e Canadá - o poder aquisitivo das camadas trabalhadoras pouco cresceu, quando cresceu, no período posterior a 1970. O sentimento consolidado de prosperidade constante fora abruptamente substituído por um quadro de estagnação, quando não de desolação.

Paralelo à estagnação econômica e ao aumento da concentração de renda, Mounk vê outros dois fatores que concorreram para aprofundar a atual crise das democracias liberais. Um deles está na emergência ao centro do palco das políticas identitárias. Ele pergunta: se a democracia permite ao povo governar, quem realmente é o povo? E diz:

$\mathrm{Na}$ altura em que os horrores da Segunda Guerra Mundial haviam sido desencadeados e se exaurido, grande parte do continente passara por uma limpeza étnica. Pela primeira na história da Europa, a maioria dos Estados podia se vangloriar da perfeita "união entre etnicidade, território e Estado" à qual tão longamente havia aspirado. E é só nesse ponto que a democracia triunfava na maior parte do continente. (2019, p. 199) 
Argumenta ainda que a homogeneidade étnica moldara os Estados nacionais que surgiram do fim da Segunda Guerra. A partir do período que ora analisamos, dos anos 1970 até então, teria tido lugar uma revolta contra o pluralismo, que, embora latente desde antes, passara a se tornar uma preocupação central entre populações recentemente sujeitas a grandes fluxos migratórios. Mounk demonstra, por meio de levantamentos estatísticos, que a imigração é considerada o principal problema político em países como Dinamarca, Hungria e Alemanha; estando entre as duas maiores preocupações políticas da população em 23 dos 24 países restantes da União Europeia ${ }^{2}$. Imersos na crise econômica e tendo ameaçados seu padrão de vida e estabilidade econômica de outrora, a intolerância latente seria um incremento em discursos políticos que buscam a responsabilização de inimigos externos e soluções simplistas para graves problemas estruturais.

Um outro fator que Mounk aponta como central é a emergência das mídias sociais. Assim resume sua visão

O que muitos observadores tomaram por um paradoxo - que as mídias sociais pudessem ter efeitos tão positivos em alguns contextos e efeitos tão negativos em outros - é resultado da mesma dinâmica subjacente: ao empoderar os outsiders, a tecnologia digital desestabiliza as elites governantes no mundo inteiro e acelera o ritmo da mudança. (2019, p. 182)

Aquilo a que alguns teóricos da comunicação designam como uma mudança da comunicação de um para muitos para um modelo de comunicação de muitos para muitos traria consigo uma maior capacidade de mobilização de agentes excluídos do status quo dominante, dentre eles os portadores de políticas extremistas, ajudando mais as "forças da instabilidade que as forças da ordem". As novas formas de comunicação e seus impactos na sociabilidade e no debate público estão no centro das principais tentativas de interpretar a dinâmica política do século XXI. As possibilidades abertas pela massificação do acesso à internet certamente são decisivas no desenrolar dos processos históricos em curso.

Acreditamos que Mounk foi preciso ao definir os sentidos ambivalentes das novas tecnologias no contexto político. Não se trata apenas de dar voz a uma multidão de imbecis, como já se sugeriu. Nem tampouco de simplesmente empoderar setores excluídos pela hegemonia da grande mídia. Os novos recursos possibilitam que discursos marginalizados possam disputar o centro do debate público, o que, em certo sentido, é democratizante. Contudo, se o sentido dos discursos emergentes nas redes sociais tem caráter democratizante é uma outra questão, inteiramente a cargo do contexto específico em que se dão as disputas políticas e dos valores produzidos e reproduzidos por seus agentes. Resumidamente, o desafio que as redes sociais na

${ }^{2}$ Constam nesta relação 27 países, ainda inclusos os países do Reino Unido. 
internet trazem à democracia é o de lidar com a afluência cada vez maior de atores e ideologias que antes eram facilmente relegados do debate público pela concentração dos meios de difusão de informação. Torna-se mais onerosa a construção de um consenso, dado que as pessoas passam a se pautar por um conjunto mais amplo de valores e possibilidades. A dispersão da capacidade de pautar o debate público nos parece muito mais relevante para o debate acerca da democracia e seus desafios que o tema recorrente da manipulação das redes por robôs ou fakenews, muito embora esses procedimentos tendam a reconcentrar a capacidade de agendamento do debate público nas mãos de poucos, dessa vez, tendo como palco, as redes sociais na internet.

\title{
3. DEMOCRACIA LIBERAL E SEU NÊMESIS
}

O dilema que se descortina diante da crise de legitimidade das democracias liberais é tipificado por Yascha Mounk nos termos da desagregação desta em dois fenômenos que marcariam as atuais perspectivas democráticas no mundo:

\begin{abstract}
Nas democracias do mundo todo, dois acontecimentos aparentemente distintos estão ocorrendo. Por um lado, as preferências do povo são cada vez mais iliberais: os eleitores estão cada vez mais impacientes com as instituições independentes e cada vez menos dispostos a tolerar os direitos de minorias étnicas e religiosas. Por outro, as elites vêm assumindo o controle do sistema político e tornando-o cada vez mais insensível: os poderosos estão cada vez menos dispostos a ceder às opiniões do povo. Como resultado, liberalismo e democracia, os dois elementos centrais de nosso sistema político, começam a entrar em confronto. (MOUNK, 2018, p. 29)
\end{abstract}

Um aspecto central das teses levantadas por Mounk está na observação de que a conjunção entre democracia e liberalismo não é tão óbvia quanto parece; aparência que teria se tornado praticamente uma evidência sobretudo devido ao êxito das democracias liberais no século XX. Para ele, o que ocorre atualmente com a democracia liberal é sua dissolução em duas partes. De um lado, o que chama de democracia sem direitos, uma configuração em que a capacidade de a população ver seus interesses transformados em políticas públicas conduz a uma conformação política, cujos resultados são restrições aos direitos e liberdades preconizados pelo liberalismo. Exemplo disso seriam leis anti-imigrantes, restrições legais à liberdade religiosa, aos direitos reprodutivos e garantias às minorias - todos expressando em maior ou menor grau maiorias eleitorais. "A promessa de dar livre expressão à voz do povo é a característica central do populismo", ele escreve, e os governos populistas, tanto pela esquerda quanto pela direita, estariam corroendo as bases da democracia por dentro da própria democracia, respaldando políticas autoritárias por meios eleitorais e legais.

O outro resultado da dissolução da democracia liberal é definido por Mounk como direitos sem democracia, um arranjo que ele atribui, essencialmente, à dissociação entre as elites dirigentes e 
a maioria da população que representam. Teríamos direitos sem democracia, por exemplo, em contextos em que cortes nacionais atribuem para si a responsabilidade pela garantia de direitos de minorias sem o devido processo de representação democrática; cortes que não são diretamente eleitas pela população, e que, embora promovam políticas democráticas, carecem de legitimidade para tal. Também teríamos direitos sem democracia em Estados que, embora preservem os valores liberais, como a proteção de minorias da ditadura da maioria, têm seus processos de seleção da elite dirigente cada vez mais sequestrados quer pelo poder econômico quer por arranjos institucionais. Há ainda as esferas políticas, como a União Europeia, os órgãos internacionais de regulação e as grandes agências financeiras interestatais que produzem políticas que efetivamente impactam na vida das pessoas, embora estas não sejam consultadas (e, como destaca o autor, talvez sequer seja possível consultá-las) para a definição de políticas que requerem cada vez mais conhecimento especializado e intervenção em âmbito supranacional. Aqui, encontramos ecos do que defendia Bobbio, ao falar dos desafios não previstos da democracia.

Mesmo entre aqueles que defendem a democracia e o liberalismo nos termos expressos por Mounk, em cuja análise nos detivemos longamente, não há consenso sobre sua visão de conjunto. Particularmente, não vemos como clara a distinção que o autor faz entre a forma clássica da democracia liberal e o resultado da dissolução desta num regime de direitos sem democracia. A democracia liberal, em seu ápice, e aceitando as consequências do fecundo estudo de Mounk, fundamentou sua legitimidade em três fatores essenciais. Primeiro, a constituição de sociedades políticas relativamente homogêneas, com a exclusão da participação nos processos eleitorais de amplas parcelas da população, incluindo aí a inexistência de muitos dos direitos que hoje são alvo de contestação pelas políticas de extrema-direita - podemos citar um exemplo modelar, o direito à união civil entre homossexuais. O voto negro universal nos EUA é uma conquista recente. A expansão dos plenos direitos de expressão cultural e religiosa sequer são realidade em boa parte dos regimes considerados democracias liberais. Segundo, a concentração da capacidade de pautar o debate público e de formar o quadro de análise deste nas mãos de poucos - agendamento e enquadramento - embora barrasse a emergência de certas pautas autoritárias, não só não as barrava a todas como também impedia que demandas oriundas das camadas subalternas ocupassem um lugar de destaque no debate público - fato que sequer as mídias sociais, por diversos fatores que renderiam um estudo à parte, conseguiram reverter. E terceiro, essa legitimidade decorreu da prosperidade material, que desfrutaram amplas camadas das populações que vivenciaram as tais democracias avançadas; fatos que não persistem. 
Levitsky e Ziblatt também repararam nessas condicionantes da trajetória das democracias liberais do centro do sistema capitalista, falando em particular do caso norte-americano:

Essa estabilidade, contudo, foi alcançada à custa da exclusão racial e de dominação unipartidária autoritária no Sul. Foi apenas depois de 1965 que os Estados Unidos se democratizaram de forma plena. E, paradoxalmente, esse processo deu início a um realinhamento fundamental do eleitorado norte-americano, que mais uma vez deixou os partidos muito polarizados. Essa polarização, mais profunda do que em qualquer outro tempo desde a Reconstrução, incitou uma epidemia de quebra das normas que hoje desafia a nossa democracia. (2018, p. 194)

Tanto Mounk quanto Levitsky e Ziblatt admitem que a prosperidade da democracia liberal foi essencialmente fundamentada numa exclusão dos processos decisórios de amplas parcelas da sociedade e numa identidade comunitária homogênea, e fica claro que ambos não propõem como solução para os impasses surgidos pela maior heterogeneidade das sociedades um regresso para um estado anterior. Mounk chega a propor medidas que visariam a reformar a democracia liberal, como o aperfeiçoamento do sistema representativo, redução das desigualdades econômicas e a domesticação do nacionalismo.

O fato que se põe diante de pesquisadores de todo o mundo é que, embora necessária, uma reforma progressista da democracia liberal está distante das perspectivas atuais, escrevendo em fins de 2020. O horizonte que se vislumbra, pelo contrário, é o da regressão democrática. Castells, na conclusão de seu Ruptura, faz uma pergunta audaciosa e lhe dá uma resposta ainda mais: "Onde estão essas novas instituições dignas da confiança de nossa representação? Auscultei muitas sociedades nas duas últimas décadas. E não detecto sinais de nova vida democrática por trás das aparências” (2018, p. 147). Sua conclusão desafiadora justifica uma transcrição literal e extensa:

\begin{abstract}
Há projetos embrionários pelos quais tenho respeito e simpatia, sobretudo porque me emocionam a sinceridade e a generosidade de tanta gente. Mas não são instituições estáveis, não são protopartidos ou pré-Estados. São humanos agindo como humanos. Utilizando a capacidade de autocomunicação, deliberação e codecisão de que agora dispomos na Galáxia da Internet. Pondo em prática o enorme caudal de informação e conhecimento de que dispomos para gerir nossos problemas. E reconstruindo de baixo para cima o tecido de nossas vidas, no pessoal e no social. Utópico? Utópico é pensar que o poder destrutivo das atuais instituições pode deixar de se reproduzir em novas instituições criadas a partir da mesma matriz. E, já que a destruição de um Estado para criar outro leva necessariamente ao Terror, como já aprendemos no século XX, poderíamos experimentar e ter a paciência histórica de ver como os embriões da liberdade plantados em nossa mente por nossa prática vão crescendo e se transformando. Não necessariamente para construir uma ordem nova. Mas sim, quem sabe, para configurar um caos criativo no qual aprendamos a fluir com a vida, em vez de aprisioná-la em burocracias e programá-la em algoritmos. Dada nossa experiência histórica, aprender a viver no caos talvez não seja tão nocivo quanto conformar-se à disciplina de uma ordem. (2018, p. 147-148)
\end{abstract}


Resignado? Pessimista? Revolucionário ou conservador? Podemos adjetivar a opinião de Castells a nosso gosto. A depender dos valores de quem avalia, ela pode se enquadrar num amplo espectro de qualidades. O que nos estimula a cometer uma citação tão extensa é o conjunto mais amplo de noções que emergem do texto do sociólogo espanhol. Vejamos, então.

Sugerimos, com base na leitura de Mounk e Levitsky e Ziblatt, que a democracia liberal enfrenta um impasse, que consiste em recepcionar as demandas crescentemente desconsideradas da população e, ao mesmo tempo, garantir as liberdades que são associadas ao liberalismo político. Um pressuposto do problema ora colocado é que é necessária a garantia da estabilidade dos regimes políticos. Portanto, sua reforma se daria por meio de suas próprias instituições. Isso implica, por exemplo, no caso da proposta de Mounk de domesticar o nacionalismo, num projeto a ser executado de cima para baixo, quer por Estados, quer por elites políticas dirigentes. Passaria tal solução por convencer as elites dirigentes a voluntariamente promover uma maior igualdade de renda, a impor barreiras para a expressão eleitoral de sentimentos nocivos aos ideais liberais? Se sim, não seria tal política um prolongamento do que o autor chama de direitos sem democracia? E talvez ainda mais importante: qual a possibilidade de êxito de tal política?

\section{O POPULISMO REACIONÁRIO E A CHANTAGEM NEOLIBERAL}

A vitória de Donald Trump nos EUA pode ser vista como o momento da virada da democracia liberal no mundo, como propõem Levitsky e Ziblatt. Essa virada se dá no sentido do populismo de direita em suas facetas mais variadas. Há fortes indícios de que o eleitorado de Trump se constituiu prioritariamente de pessoas residentes em localidades deslocadas do polo dinâmico da economia globalizada, na maioria, trabalhadores de baixa especialização com níveis inferiores de escolaridade. Essa é a base social nuclear dos populismos de direita que crescem no mundo, especialmente na Europa.

Correntes populistas se beneficiaram das possibilidades abertas pela emergência de novas formas de comunicação, especialmente as mídias sociais, pois puderam criar novos espaços de organização, formação e mobilização de suas bases (CASTELLS, 2018; MOUNK, 2018). Castells escreveu:

Em todas as sociedades, os setores sociais mais vulneráveis são os que reagem, movidos pelo medo, a mais poderosa das emoções, e se mobilizam em torno daqueles que dizem aquilo que o discurso das elites não lhes permite dizer. Daqueles que sem rodeios articulam um discurso xenófobo e racista. Daqueles que apelam para a força do Estado como forma de resolver as ameaças. Daqueles que simplificam os problemas mediante a oposição entre os em cima e os em baixo. E daqueles que denunciam a corrupção imperante em todo o canto, embora em muitos casos eles e elas façam parte da mesma corrupção. (2018, p. 37) 
O mundo que sobrevive à Guerra Fria é um mundo hegemonizado pelo modelo neoliberal, de redução da presença do Estado na economia, do desmantelamento das políticas de proteção social e da paulatina precarização do trabalho. Na política, o mundo neoliberal tornou-se cada vez mais elitista, menos afeito à participação popular e cada vez mais dependente do consenso forjado pela concentração dos meios de comunicação de massa. É simbólico que a crise final da coalizão tatcherista tenha se dado no momento em que a primeira ministra inglesa propunha a instituição de um imposto sobre o direito ao voto ${ }^{3}$ - era o ideário fundamentalista ultraliberal cada vez mais convicto da ausência da necessidade de fazer concessões ou de incorporar o povo nas decisões. O devaneio neoliberal recuou nessa medida particular, fez novas rodadas de concessões parciais, mas no essencial seguiu dobrando a aposta até que o consenso se tornasse insuportável. Por isso, tem importância a noção de Castells ao apontar que o século XXI vivencia o colapso da democracia liberal. Contudo, há também fortes indícios de que ela possa sobreviver, sem que isso represente uma melhora na qualidade de vida das populações ou mesmo na qualidade da própria democracia.

Arjun Appadurai, em seu ensaio Fadiga da democracia, propõe que

\begin{abstract}
$\mathrm{Na}$ ausência de uma economia nacional que os Estados modernos possam alegar que protegem e fortalecem, não é surpresa ter havido uma propensão a que Estados de fato, bem como diversos movimentos populistas em ascensão, tentem reencenar a soberania nacional por meio do chauvinismo cultural dominante, do etnonacionalismo e da opressão às dissidências intelectuais e culturais internas. Em outras palavras, a perda generalizada da soberania econômica gera uma mudança rumo à ênfase na soberania cultural. (APPADURAI, 2019, p. 21)
\end{abstract}

Muito embora a economia esteja no cerne da crise de legitimidade das democracias liberais, de forma aparentemente contraditória, soluções para o problema do baixo crescimento e da crescente desigualdade econômica não constam dos programas, quando os há, dos populismos emergentes. A hegemonia global dos interesses ligados aos mercados financeiros permanece intacta diante da onda de governos populistas. E isto é expressão de um fenômeno mais amplo.

Nas análises de Mounk e Castells, há flagrantes oposições acerca das implicações da crise que ora debatemos. Uma delas, exemplar a fim de esclarecer nosso ponto de vista, se dá na avaliação dos atores políticos que disputam as saídas da atual crise. Mounk, ao elencar os grupos políticos cuja ascensão representariam o crescimento do populismo nas democracias ocidentais, não tergiversa ao incluir o Podemos, da Espanha, e o grego, Syriza, vistos como representantes de um populismo de esquerda. Em ambos os casos, podemos imaginar com base em nossas leituras de Castells que este responderia: inimigos do consenso neoliberal, sim; mas não da

\footnotetext{
${ }^{3}$ Ver Wheen (2007), p. 54-55.
} 
democracia; populares, mas não populistas. É claro que aqui incorremos nos riscos inerentes à dedução.

Mounk resume o populismo nos seguintes termos: "O que define o populismo é essa reivindicação de representação exclusiva do povo - e é essa relutância em tolerar a oposição ou respeitar a necessidade de instituições independentes que com tamanha frequência põe os populistas em rota de colisão direta com a democracia liberal” (2019, p. 10). Nessa definição, há pontos importantes a serem analisados. Um primeiro, que nos parece mais óbvio, é o da recusa em aceitar a existência da oposição, ou, nos termos de Levitsky e Ziblatt, a tolerância mútua. Uma bem-acabada expressão desse sentimento, a intolerância, pode ser encontrada nos primeiros discursos de Jair Bolsonaro, quando eleito em 2018, em que prometia varrer do país a escória vermelha. As tentativas de supressão ou repressão aos dissidentes são marcas preocupantes dos novos populismos, bem como o foram em os movimentos ou governos de viés autoritário, comportamento muito bem documentado em Como as democracias morrem, no contexto dos EUA. Contudo, a relação dessa prática com o discurso de representação exclusiva do povo, como propõe Mounk, não é tão evidente. Quando os movimentos sociais antissistema questionam a legitimidade da representação política estabelecida, o que se expressa em palavras de ordem como eles não nos representam, ou mesmo generalizações no sentido de que o sistema político como um todo é viciado e antipopular, não estão negando o direito à existência do divergente. O que esse discurso expressa é o fato inconteste (e reconhecido pelo próprio Mounk como um dos fatores centrais da crise das democracias liberais) de que, nas democracias liberais, o descompasso entre representantes e representados é cada vez maior. O fato de o populismo de direita se apropriar desse sentimento de distanciamento não significa que ele seja apenas um artifício retórico. A decrescente legitimidade da representação política é um fato, fato que encontra nos movimentos sociais antissistema e nos populismos reações distintas. Os movimentos sociais contestatórios organizam parcelas da população num modelo de contraposição às elites bem diferente daquele do populismo, caracterizado pelo tratamento do povo como sujeito atômico, disperso numa massa informe.

Quanto ao outro elemento do populismo, conforme definido por Mounk, o respeito às instituições independentes da democracia também é necessário fazer uma distinção. Como os autores que discutimos registram, a esfera da política tem se reduzido por distintas pressões. Primeiro, temos aquilo que Bobbio chama de o governo dos técnicos. A complexificação das sociedades, das demandas feitas ao Estado pelos sistemas democráticos e a especialização que se faz cada vez mais necessária para o entendimento e deliberação acerca de temas de interesse 
coletivo, somadas, ampliou enormemente o conjunto das políticas às quais uma deliberação pública se torna cada vez de mais difícil execução. Por outro lado, as instituições de controle, muitas vezes não eleitas diretamente pela população (Justiça, Tribunais de Conta etc), ocupam cada vez mais o centro das decisões políticas. A democracia liberal, e seu sistema de freios de contrapesos, tem nos mesmos elementos que lhe conferem estabilidade fatores de contenção da participação popular nas decisões políticas, criando desestímulos à livre expressão de determinadas ideias. E isso está longe de ser uma questão simples de se resolver. Tomemos como exemplo as agendas de costumes que, desde os anos 1960, se estabeleceram como temas centrais do debate público. Os movimentos portadores dessas agendas conseguiram lograr notáveis êxitos nas décadas que se seguiram, sobretudo, no que concerne aos direitos de liberdade reprodutiva e sexualidade. Contudo, nada indica que essa agenda tenha em algum momento obtido consentimento majoritário das populações dos países onde fizeram seus avanços. Mesmo no Brasil, muitos dos direitos hoje assegurados a minorias historicamente perseguidas foram alcançados por meio de decisões em tribunais e instâncias que não se submetem ao escrutínio do voto. Não temos nenhuma concessão a fazer a respeito de tais conquistas, independente dos mecanismos pelos quais foram obtidas. Também não pretendemos abdicar dos valores democráticos em função de um novo despotismo esclarecido. De tais posicionamentos emergem, contudo, acentuadas contradições. Uma delas diz respeito à difícil demarcação entre temas que podem legitimamente ser decididos por tribunais e aqueles sobre os quais a ação do Judiciário é ilegítima e regressiva. Como separar a preocupante judicialização da política (expressa sobremaneira no protagonismo do Poder Judiciário na definição das eleições presidenciais de 2018 no Brasil) do protagonismo do Judiciário na promoção de direitos (uma vez que o Parlamento, a quem caberia tal responsabilidade, se esquiva, por motivos eleitorais, de deliberar sobre questões prementes como os direitos reprodutivos e tantos outros temas polêmicos), sobretudo na ausência de um amplo consenso em torno de ambas as iniciativas?

Um outro ponto que pretendemos evidenciar é que a democracia liberal em todo o mundo tem se sustentado exatamente na interdição do debate acerca dos fundamentos econômicos que regem a produção e as trocas, bem como as relações de trabalho, e que nem todos os movimentos que se apresentam como antiestabilishment podem ser adequadamente classificados sob o rótulo de populistas. Há numerosos movimentos sociais que legitimamente têm se oposto ao sistema numa busca por aprimorar a experiência democrática, incluindo na pauta política temas essenciais à vida das populações de seus países. Contudo, sob o discurso da defesa das democracias liberais, há uma chantagem implícita: sua defesa deve se dar nos termos exclusivos 
da preservação da hegemonia econômica do capital financeiro mundial, muito bem representado nos atuais arranjos institucionais. É a isso que chamamos neste artigo de chantagem neoliberal. Os Estados nacionais seguem, no populismo ou na democracia liberal anterior a ele, impotentes diante da realidade econômica, tendo suas políticas severamente limitadas pelos interesses hegemônicos, sendo incapazes, portanto, de construir saídas para o grave cenário econômico e social em que se afundam as democracias do sistema capitalista. Por isso, de forma trágica, as propostas de frente ampla democrática que surgem trazem a nefasta consequência da interdição das políticas de esquerda, submetidas à tirania das políticas de austeridade.

No Dicionário de Política, o verbete populismo assim resume o conceito:

Podemos definir como populistas as formas políticas cuja fonte principal de inspiração e tema constante de referência é o povo, considerado como agregado social homogêneo e como exclusivo depositário de valores positivos, específicos e permanentes. (INCISA, 2016, p. 980)

Teríamos próximos a nossa realidade política exemplos incontestes de populismo no peronismo argentino e no varguismo brasileiro. Contudo, apesar de tipos consensualmente considerados populistas, a literatura sobre o tema apresenta grandes variações e divergências (INCISA, 2016). Sob o rótulo de populista, tem-se agrupado experiências distintas como os governos de Evo Morales, na Bolívia, e de Vladimir Putin, na Rússia. Se considerados todos os usos do conceito de populismo, conforme aparecem na literatura contemporânea, teríamos sob sua abrangência todos os governos que por quaisquer meios busquem alternativas ao monopólio político e ideológico do consenso neoliberal e dos limites da democracia liberal existente.

Problematizadas algumas das principais obras interpretativas da atual crise democrática, propomos que o impasse que se apresenta às democracias liberais é lido e tem suas possíveis saídas circunscritos ao modelo hegemônico neoliberal. Para avançar nessa discussão, buscamos em Nancy Fraser o conceito de neoliberalismo progressista, que tem seu oposto relacional no populismo reacionário. Os conceitos de Fraser possuem sobre aqueles propostos por Mounk (democracia sem direitos e direitos sem democracia) uma clara vantagem: situam a atual contenda em torno da democracia no terreno das disputas entre forças neoliberais, tornando patentes os limites democráticos dos dois modelos que competem pela representação política nos países de democracias liberais.

Analisando a vitória de Trump nos EUA e outras revoltas eleitorais antissistema, como o surpreendente desempenho de Bernie Sanders nas primárias democratas, Fraser conclui que

Apesar de diferirem nas ideologias e objetivos, esses motins eleitorais têm um destino em comum: todos representam a rejeição da globalização corporativa, do neoliberalismo e dos sistemas políticos que os promovem. Em todos os casos, os eleitores estão dizendo "Não!" à mistura fatal de austeridade, livre comércio, dívida 
predatória e trabalho precário e mal pago que caracterizam o capitalismo financeirizado atual. Seus votos representam a contrapartida política subjetiva à crise estrutural objetiva dessa forma de capitalismo. (FRASER, 2019, p. 77)

É patente nos atuais debates sobre o comportamento político que mesmo o voto ideológico possui, em amplas parcelas da sociedade, baixa estruturação cognitiva (FIGUEIREDO, 2008). Sendo conceitos relacionais, conforme propõe Bobbio (2018), esquerda e direita se sedimentam nas preferências do eleitorado a partir dos processos políticos concretos em que os projetos concorrentes se movem ao longo do espectro ideológico. No Brasil, parte do eleitorado lulista ${ }^{4}$ aderiu à candidatura de Bolsonaro $^{5}$, no que pode ser interpretado como um voto antissistema. Tal hipótese condiz com a proposição de Fraser de que o populismo reacionário se alimenta da frustração crescente com o modelo econômico predominante. Embora acrescentemos à hipótese de Fraser que o conservadorismo cultural também possui fortes raízes nos estratos populares, seus conceitos nos permitem levar a discussão sobre o caso brasileiro adiante, pois explicam como puderam as agendas libertárias dos movimentos sociais serem incorporados pelo discurso neoliberal.

No caso americano, a agenda inclusiva dos movimentos sociais teria se alinhado, pelos processos de disputas políticas desde os anos 1960, ao modelo econômico liberalizante que depreciou as condições do trabalho e fragilizou as estruturas de proteção social. Para Fraser, o governo Clinton seria a expressão mais bem-acabada dessa junção, expressa na absorção e ressignificação dos ideias feministas e igualitários por meio de valores individualistas e meritocráticos.

\footnotetext{
Identificando o progresso com a meritocracia em vez da igualdade, esses termos equiparavam a emancipação com o surgimento de mulheres, minorias e gays 'talentosos' na hierarquia corporativa em que o vencedor leva tudo, em vez de fazê-los por meio da abolição dessa hierarquia. (FRASER, 2019, p. 80)
}

Dessa forma, os ideais de igualdade teriam se confundido com o neoliberalismo hegemônico no plano do debate público. Podemos acrescentar ao diagnóstico a expressão comercial da absorção desses ideais pela publicidade, que, através de práticas de consumo, propõem um modelo de empoderamento, conforme vemos em propagandas comerciais que se

\footnotetext{
4 Aqui, entendido nos termos de André Singer (2013) como um reformismo fraco, tendo como eixo a integração de vastas parcelas do subproletariado no mercado formal, via expansão do trabalho na base da pirâmide, e no consumo, via políticas redistributivas e de ampliação do crédito, num contexto de conciliação dos interesses de classe cujo objetivo é evitar a conflagração de conflitos abertos que possam ameaçar as parcas conquistas sociais e econômicas das parcelas mais vulneráveis da sociedade.

${ }^{5}$ Ver mais em MOURA e COBERLLINI (2019).
} 
valem da representatividade étnica, sexual, etc para construir a identidade dos produtos que vendem.

Compreendendo a análise de Fraser sobre tal dinâmica política no contexto mais amplo exposto por Appadurai, se justifica o que a primeira diz ao propor que estamos diante de uma "escolha de Hobson", ou como propomos, de uma chantagem neoliberal. Nos termos dessa chantagem, estaríamos limitados a escolher entre o menor de dois males, o neoliberalismo progressista ou o populismo reacionário. Escolha que, como demostra Appadurai, se dá nos limites do modelo neoliberal hegemônico ao qual nenhuma das alternativas pretende ou pode se contrapor.

Em sua análise sobre o capital no século XXI intitulada A loucura da razão econômica (2018), David Harvey expõe os mecanismos pelos quais o valor agregado pela produção é distribuído entre os mais diversos atores da economia global. A distribuição final do mais-valor produzido pelo trabalho se espalha ao longo da cadeia produtiva indo do produtor direto, o capitalista empresário do setor produtivo, ao Estado via tributos, aos comerciantes via divisão dos lucros e ao sistema financeiro através dos juros. Este último desempenha nos ciclos produtivos um papel essencial ao normalizar as temporalidades distintas de cadeias de produção, cujos tempos de reprodução podem variar grandemente. Ao organizar a distribuição de capitais e permitir que recursos não fiquem paralisados entre o período de produção e realização de mais valor, o sistema financeiro aumenta a disponibilidade de capital para investimento, bem como gera todo um mercado paralelo baseado na expectativa de ganhos futuros.

Nas últimas décadas, os incrementos tecnológicos conferiram ao sistema financeiro maior dinamicidade e abrangência. O fluxo de capitais pelo planeta se dá instantaneamente. Volumes de dinheiro equivalentes ao produto interno de muitas nações migram de um território a outro em questão de segundos. Linhas de produção, alocação de mão de obra, fornecimento de recursos naturais espalham-se pelo globo. Um dos grandes feitos da economia marxista é demonstrar como a base do valor que circula pelos mercados se constitui através do trabalho. Se todo o valor distribuído nas esferas econômicas provém do trabalho, há duas formas essenciais de obter maior lucratividade: o aumento das horas trabalhadas por cada indivíduo e o incremento na produtividade da hora trabalhada. Estamos aqui diante dos clássicos conceitos de mais valia absoluta e relativa.

Ocorre que a participação do capital financeiro sobre o valor produzido vem crescendo década após década, como aponta Harvey. Com a redução de suas parcelas no montante do mais valor produzido, produtores e comerciantes precisam recompor as margens de rendimento. Uma 
das formas de recomposição a que se tem recorrido é a financeirização do próprio capital produtivo. Empresas alocam seus recursos nos mercados financeiros em busca de lucros imediatos e de simples realização, num processo de hibridização entre capital produtivo e financeiro que em última instância aumenta as pressões sobre o primeiro, de onde surge o valor distribuído. A pressão do capital financeiro, de forma resumida, leva os setores industriais e comerciais à busca desesperada por recompor sua própria participação na distribuição do mais valor. Daí, decorrem duas possibilidades que são o pilar das variantes mais diversas do neoliberalismo: a redução do contingente de valor distribuído aos trabalhadores via salários e ao Estado via tributos.

A compreensão dos complexos mecanismos pelos quais se dá a reprodução do capital e a distribuição do mais valor está longe de ser tarefa simples, embora não seja uma meta exclusiva a iluminados - a obra de Harvey é poderosa em esclarecer tais mecanismos e desmistificá-los. Para poder avançar na discussão presente, aceitaremos as conclusões derivadas da leitura de Harvey e apresentadas nos parágrafos anteriores, o que nos leva a uma compreensão das forças que movem o projeto neoliberal, centrado na redução do Estado e na desvalorização do trabalho via precarização e arrocho salarial.

As políticas públicas - sobretudo aquelas voltadas aos serviços essenciais e à proteção social - são ferramentas redistributivas essenciais para a reprodução social no capitalismo, cujos impactos constatamos anteriormente ao discutir as políticas de bem-estar social. Contudo, o novo padrão de acumulação financeirizado hegemônico desde os anos 1970 - aquilo a que chamamos de neoliberalismo - necessita, como vimos, reduzir os custos da reprodução social contidos nos salários e tributos para manter o sistema produtivo viável, tendo em vista a busca individual do lucro pelo capitalista do setor produtivo.

Um dos mecanismos adotados é a transferência da responsabilidade pela reprodução social dos sistemas de proteção do Estado para camadas marginalizadas da sociedade. Esse fenômeno está explicitado na denúncia de Fraser sobre o papel do trabalho doméstico não remunerado na reprodução social como forma de intensificar a exploração do trabalho das mulheres. Outro é a desregulação das relações de trabalho e a constante migração da alocação de mão de obra. Em ambos, é o Estado o agente central, quer como mediador e regulador das relações trabalhistas, quer como provedor das políticas de proteção social. Dessa forma, é o papel do Estado na economia o centro das disputas em torno do projeto neoliberal. Questões identitárias, direitos de minorias - no que se limita ao direito meritocrático de competir, ainda que em bases desiguais - e liberdades civis não são necessariamente basilares para o modelo econômico neoliberal. Assim 
compreendemos que a polarização entre o neoliberalismo progressista e o populismo reacionário possa se dar nos limites da hegemonia neoliberal. A "ameaça fascista", ou a regressão democrática, nesse contexto, induzem as forças de esquerda a uma barganha nada promissora.

Nancy Fraser defende a ausência de uma "esquerda verdadeira" é que possibilita a chantagem neoliberal. Uma vez que o populismo reacionário se alimenta da desilusão e da revolta com os resultados da globalização financeirizada, a ausência de um contraponto de esquerda à globalização financeirizada deixaria as camadas populares excluídas à mercê do discurso populista. Podemos questionar essa alegação apontando que há vários movimentos de contestação com orientação de esquerda - muitos deles tidos como populistas também, por grande parte da literatura contemporânea - que não logram a mesma adesão popular a seus projetos. Se o problema está no projeto ou nas bases sociais que o sustentariam (no caso, na falta de bases sociais), é um desafio ao qual nos limitamos a problematizar, por ora.

\section{CONCLUSÃO}

A democracia liberal hegemônica no bloco capitalista conviveu muito bem com ditaduras sem direitos e sem democracia. A história da América Latina no século XX é prova inconteste desse fato. Ela teve boa performance nos países centrais do sistema capitalista enquanto foi capaz de conter as demandas vindas dos de baixo e entregar prosperidade material e paz para amplas camadas de suas populações, bem como concentrar o debate público em torno de variantes de seus interesses. No início da década de 1970, contudo, as bases da prosperidade foram abaladas. O incremento tecnológico introduziu um novo patamar de competitividade numa economia cuja linha de produção passara a ser multinacional. Em busca de produzir mercadorias a custos cada vez mais baixos, indústrias passaram a contratar mão em obra de países periféricos. O drama decorrente desse deslocamento, dentro dos países do centro capitalista, foi magistralmente narrado em Pastoral Americana, do escritor Philip Roth. Agravando a crise, milhões de pessoas se viram diante da necessidade de emigrar, vítimas de profundas e permanentes crises econômicas e de guerras civis muitas delas geradas pela configuração dos Estados nacionais no pós-guerra, que, conforme expôs Hobsbawm (1984), foram baseados sobre premissas étnicas e culturais no mais das vezes artificiais, demonstrando a fragilidade de um dos pilares da estabilidade democrática conforme sugeridos por Mounk.

A atual crise das democracias liberais está intimamente ligada aos resultados das décadas de hegemonia neoliberal. Suas consequências podem representar um severo regresso nas conquistas 
liberais acumuladas ao longo de séculos de lutas políticas e desenvolvimentos institucionais baseados num doloroso aprendizado político.

Ao se confrontar com a emergência do populismo reacionário, as forças democráticas se põem diante do dilema de ou recuar em sua agenda social e política ou perder a oportunidade de formar amplas coalizões (incluindo aí os atores portadores do que Fraser chama de neoliberalismo progressista) e aumentar as chances de barrar uma escalada autoritária cujos resultados podemos apenas supor.

Parece-nos, portanto, muito mais provável que a retomada da estabilidade dentro do próprio regime se dê pelo aumento da exclusão das camadas populares do debate político, consolidando aquilo que Mounk chamou de direitos sem democracia, que pensamos não ser um resultado da dissolução da democracia liberal, mas sim sua forma clássica nos países de democracias reais. Cabe ainda registrar que os direitos que se busca garantir em tais arranjos nada mais são que os direitos de liberdade individual, sobretudo centrados nos costumes, de expressão e livre organização - e concordamos que, só por isso, a defesa das democracias liberais já se justifica. Contudo, nada se diz sobre a estagnação de direitos sociais, e mesmo sua regressão, que não seja facilmente contestado. Direitos sem democracia são o que chamamos com certa imprecisão de democracia real neste trabalho, ao que nos referimos ao arranjo institucional dominante nos países do centro do capitalismo mundial, seguindo as definições de Bobbio. Nesse sentido, partindo das definições do próprio autor, o livro de Mounk deveria se intitular O povo contra o liberalismo, no sentido em que o que ocorre nos países centrais do sistema é a emergência da outra forma em que se constituiu a democracia liberal ao longo do século XX, aquilo a que Mounk chama de democracia sem direitos.

O uso abrangente do conceito de populismo se presta a pôr no mesmo campo o populismo reacionário e os movimentos sociais antissistema, embargando o debate público das ideias de esquerda que proponham um enfrentamento mais efetivo ao neoliberalismo. As premissas da estabilidade política e da preservação de instituições democráticas enrijecidas impõem severas limitações a qualquer projeto mais ambicioso de transformação das democracias liberais. Volta-se, dessa forma, ao velho debate de como preservar a democracia. Há quem sugira que nada é mais perigoso à democracia que o excesso de democracia. Há quem proponha que a democracia se sustenta avançando sempre no sentido de mais democracia. Embora nos alinhemos a essa última concepção, é necessário não subestimar o fato de que - diante da fragilidade dos projetos políticos de esquerda e da crescente dificuldade de mobilização social em torno de programas amplos e coletivos, progressistas e universalizantes - há dilemas reais ao se 
decidir investir contra instituições que já não correspondem aos anseios da população. A questão que sobra é: seria sensato, diante dos riscos reais de degradação da frágil e limitada democracia real que vivenciamos, investir num projeto de ruptura com o modelo hegemônico? Cautelosamente, cremos que sim; sobretudo, porque não nos parece haver alternativa.

\section{REFERÊNCIAS}

APPADURAI, A. 2019. Fadiga da democracia. In: APPADURAI, A. et al. A grande regressão. São Paulo: Estação Liberdade.

BOBBIO, N. 2018. O futuro da democracia. Uma defesa das regras do jogo. $15^{\mathrm{a}}$ edição. Rio de Janeiro: Paz e Terra.

CASTELLS, M. 2018. Ruptura: a crise da democracia liberal. Rio de Janeiro: Zahar.

FIGUEIREDO, M. 2008. $A$ decisão do voto. Rio de Janeiro: IUPERJ.

FRASER, N. 2019. Neoliberalismo progressista versus populismo reacionário: a escolha de Hobson. In: APPADURAI, A. et al. A grande regressão. São Paulo: Estação Liberdade.

HARVEY, D. 2018. A loucura da razão econômica: Marx e o capital no século XXI. São Paulo: Boitempo.

HOBSBAWM, E. 1984. "Introdução" In: HOBSBAWM, E., RANGER, T. A invenção das tradições. Rio de Janeiro: Paz e Terra.

HOBSBAWN, E. 1995. A era dos extremos: o breve século XX. 1941-1991. São Paulo: Companhia das Letras.

HOBSBAWM, E. 2007. Globalização, democracia e terrorismo. São Paulo: Companhia das Letras.

INCISA, J. 2016. Populismo. In: BOBBIO, N., MATTEUCCI, N., PASQUINO, G. Dicionário de Política. Brasília: Universidade de Brasília.

LEVITSKY, S., ZIBLATT, D. 2018. Como as democracias morrem. Rio de Janeiro: Zahar.

MOUNK, Y. 2019. O povo contra a democracia: por que nossa liberdade corre perigo e como salvá-la. São Paulo: Companhia das Letras.

MOURA, M., CORBELLINI, J. 2019. A eleição dismuptiva. Rio de Janeiro: Record.

SINGER, André. 2012. Os Sentidos do Lulismo: Reforma gradual e pacto conservador. São Paulo: Companhia das Letras. 